\title{
Competency Analysis of Job Satisfaction and Organizational Commitment to Lecturers Who Teach at Private Universities in the Area of Southern Sumatra
}

\author{
Zainal Berlian \\ University Raden Fatah, Palembang, South Sumatera, Indonesia \\ willy.arafah@gmail.com
}

\begin{abstract}
The most important thing in an organization is how an organization is managed well, including the readiness of human resources to deal with changes that occur so quickly. Competence will be very influential on job satisfaction and organizational commitment both in the short and long term, therefore to achieve the vision and mission that the organization has established, the organization must be able to create job satisfaction and organizational commitment. This research was conducted on lecturers who taught at private universities in Palembang as many as 254 respondents from undergraduate and postgraduate education who had five years of experience as lecturers. There is a positive influence between competency on job satisfaction and organizational commitment, meaning that to create job satisfaction and organizational commitment in an organization, competencies are needed in accordance with the field of work. Therefore the suggestion in this study is to improve the competence of lecturers who teach, either through additional education or further education which can create job satisfaction and organizational commitment both in the short and long term. the managerial implication is that the university must be able to provide a budget to improve job satisfaction and organizational commitment through efforts to improve the competence of teaching lecturers.
\end{abstract}

Keywords: Competence, job satisfaction, organizational commitment

\section{INTRODUCTION}

Important things we need to know that make the organization run smoothly and well are Organizational Commitment, said by Baron and Greenberg (2003) stating organizational commitment is one's identity and involvement in the organization and has no desire to leave the organization so the organization can run smoothly and effective. Luthan (2006) Organizational commitment is; (1) a strong desire to remain a member of an organization or community; (2) great willingness to strive for the organization; and (3) trust and acceptance of organizational values and objectives.In addition there are good performance factors such as organizational commitment that are also very much needed for the company. It is still closely related to organizational commitment, Compentesis is a problem that concerns employees in an organization and company, Competence itself in Levine's writing, (1997) states that Competition problems are things that are commonly encountered in every company. Competence has received much attention and is seen as a method for direct review to focus attention on management systems that contribute to the success and sustainability of the organization, if competencies, skills, ideas and employee workforce are used properly then the organization will run effectively and efficiently that affect Employee satisfaction. The research questions are: (1). Does Competence affect Job Satisfaction? (2). Does competition affect organizational commitment? ? (3). Does Job Satisfaction affect Organizational Commitment?

\section{LITERATURE REVIEW}

The concept of competency includes the creation of consistently high-performance business levels that are important for business sustainability, this is a critical criterion in training and development, performance 
Competency Analysis of Job Satisfaction and Organizational Commitment to Lecturers Who Teach at Private Universities in the Area of Southern Sumatra

evaluation, career development, remuneration and recruitment decisions by human resource management. This can be seen as knowledge, skills and abilities that distinguish high performance from average performance, because a structure that helps to determine knowledge and skill levels, as observable behavioral characteristics that are important for realizing Competence possessed by a business is a collection of characteristics and the skills of the existing workforce Differences in employee skills and competencies make company competencies different Alldredge \& Nilan, (2000). According to Robbins and Judge (2015) said Job Satisfaction as a positive feeling about someone's work which is the result of an evaluation of its characteristics. Job Satisfaction is a reflection of employees' feelings for their work. Robbins and Judge (2015) define Job Satisfaction as a general attitude of an individual to his work, the difference between the many rewards a worker receives and the amount they believe they should receive. Job Satisfaction is determined by several factors, which are mentally challenging work, supportive working conditions, supportive coworkers, and suitability of personality to work. The two-factor theory is the Job Satisfaction theory which advocates that satisfaction and dissatisfaction are part of a different group of variables namely motivation and hygiene factors. In this theory, dissatisfaction is related to the conditions around work (such as working conditions, wages, security, quality of supervision, and relationships with others) rather than the work itself.Because this factor prevents negative reactions, it is called hygiene or maintenance factors. Definition of Organizational Commitment According to Raisah (2015); Mowday (1985) Organizational Commitment is an important behavior that can be used to assess the tendency of employees to survive as members of the organization. Organizational Commitment is the identification and involvement of someone who is relatively strong towards the organization. Organizational Commitment is the desire of organizational members to maintain their membership in the organization and are willing to strive for the achievement of organizational goals.

According to Spencer and Spencer (2000), competency is a basic characteristic of a person, namely: character, motives, self-concept, knowledge and skills that can influence behavior and ability to produce work performance and job satisfaction.

H1: Competency affects job satisfaction

Competence and organization are basically resource exchange contracts between two employees and the company Aggarwal \& D'Souza, (2012). Homans, in the context of how individuals interact in organizational groups and are committed to Blau (1964)

H2: Competence affects organizational commitment

Luqman et al. (2012) state that the quality of public services in the Nigerian Public Service will increase if employees are satisfied and happy with their work. Job satisfaction plays an important role in shaping discipline, organizational commitment and employee performance

H3: Job Satisfaction affects Organizational Commitment

\section{RESEARCH METHODS}

The research design that will be used in this research is quantitative research design, with survey methods. According to Sugiyono (2013) the survey method was used to obtain data from certain natural (not artificial) places, but the researchers treated the data collection, the results of distributing questionnaires. The type of research used in this study is associative. Associative research is a form or method used to connect two or more variables. With this associative research we can find out the influence between the variables used. The intended unit of analysis is employees, which are obtained from the employees only collected once at a certain time or also called cross sectional.The method of this research is convenience sampling where sampling techniques are based on the ease of obtaining research respondents. The sample chosen is employees at various companies in the Jakarta area. A sample of around 254 people, according to Loehlin, recommended at least 100 samples, preferably 200. Hoyle also recommended a minimum sample size of 100-200. Anderson and Gerbing agreed 
Competency Analysis of Job Satisfaction and Organizational Commitment to Lecturers Who Teach at Private Universities in the Area of Southern Sumatra

that 100 to 150 subjects were satisfactory minimum sample sizes when building structural equation models (in Schumacker and Lomax, 2010). The data obtained and used in this study come from the primary data in the form of a list of questions and statements from the questionnaire to measure Competency variables on social exchange, job satisfaction and organizational commitment. This study uses a used trial to measure the reliability and validity of the measuring instrument. The validity and reliability test of the research questionnaire was carried out with the help of SPSS software using Cronbach's alpha reliability technique. Validity test with SPSS software can be seen based on the values contained in the corrected item total correlation column where the benchmark for evaluating valid items is 0.200 Nisfiannoor, (2013).

To test the reliability or consistency of a measuring instrument, it is known from the Cronbach's Alpha coefficient. The minimum acceptable coefficient is 0.60 Now \& Bougie, (2013). The basis for decision making is as follows:

1. If the Cronbach's Alpha coefficient is $>0.6$ then the indicator is reliable.

2. If the Cronbach's Alpha coefficient is $<0.6$, the indicator is not reliable.

\section{RESULTS AND DISCUSSION}

Table1. Regression Resulted Test Model LISREL Standardized Solution

\begin{tabular}{|c|c|c|c|c|}
\hline Variable & Variable & Cooficient & T Value & Noted \\
\hline Competence & Job Satisfaction & 0.71 & $3.47>1,96$ & Sig \\
\hline Competence & Organizational Commitment & 0,08 & $0.51<1,96$ & Not Sig \\
\hline Job Satisfaction & Organizational Commitment & 0.36 & $4.84>1,96$ & Sig \\
\hline
\end{tabular}

Sources : Statistical Resulted

Hypothesis H1: There is a significant effect of Competence on Job Satisfaction.

Based on the results of data analysis it is known that the value of $t$ values $=3.47$. Because the value of $t>1.96$ then $\mathrm{H} 0$ is rejected and $\mathrm{H} 2$ is accepted, which means there is a positive influence Competence on Job Satisfaction Thus the better / positive Competence the better / positive Job satisfaction, on the contrary the more ugly / negative Competence gets worse / low Job Satisfaction.

Hypothesis H2: There is no significant effect of competency on organizational commitment.

Based on the results of data analysis it is known that the value of $t$ values $=0.51$. Because the value of $t>1.96$ then $\mathrm{H} 0$ is rejected and $\mathrm{H} 3$ is rejected, which means there is no positive effect of Competence on Organizational Commitment with Competence Does Not Affect Commitment Organization

Hypothesis H3: There is a significant effect of Job Satisfaction on Commitment

Based on the results of data analysis it is known that the value of $t$ values $=4.84$. Because the value of $t>$ 1.96 then H0 is rejected and H6 is accepted, which means that there is a positive effect of Job Satisfaction on Organizational Commitments Thus the better / positive Job Satisfaction the better / positive Organizational Commitment, on the contrary the more ugly / negative.

\section{CONCLUSION}

1. There is a significant influence between Competence $(\mathrm{X})$ and Job Satisfaction (Y2) with a Coefficient value of 0.51 and tv value of 3.47> 1.96 which states that these two variables are significant. Based on the above, it can be stated that there is an influence between Competence (X) on Job Satisfaction (Y2). The results of this study support the opinion of Siniša et al (2016) that indeed Organizational Culture has an influence with Organizational Commitment. When viewed from the results of observations of the employee respondents 
Competency Analysis of Job Satisfaction and Organizational Commitment to Lecturers Who Teach at Private Universities in the Area of Southern Sumatra

confident in their ability to do a job within the company so as to encourage the company to be motivated to encourage employees to work harder, with reciprocity between employees and the company to make employees satisfied that can be seen in the table with a total coefficient value of 0.51 the level of satisfaction has a significant number which means that job satisfaction is high which affects the company where if the job satisfaction is high then the employee is more motivated in working and doing the assigned assignments. based on the above results the results of this study support the opinion of Ugur Yozgat (2016).

2. There is no significant influence between Competence $(\mathrm{X})$ on Organizational Commitment $(\mathrm{Z})$ with a coefficient value of 0.07 and tv value of $0.51<1.96$ thus there is no influence between Competence $(\mathrm{Y})$ and Organizational Commitment (Z) and the implications for the company. this can be based on employees who feel they have competence but are not valued by the company, causing turmoil that arises to not commit to the company which results in employees wanting to leave the company because the performance results are not valued and there is no attention from the company to employee welfare.

3. There is a significant influence between Job Satisfaction (Y2) on Organizational Commitment (Z) with a coefficient of 0.38 and tv value of 4.84>1.96 Based on the above, it can be stated that there is an effect of job satisfaction (Y2) on organizational commitment (Z), with the satisfaction of work, this will bear good fruit on the employees' commitment to the company so that they feel that the company that will become a hold and employees will continue to spend the rest of their careers with high loyalty, this must also be in line with the company's thinking employees are valuable assets in the company so that both companies and employees alike have the motivation to move forward and develop together based on the above. The results of this study support the opinion of Mowday et al., (1979); Sarker et al., (2003); Steers), (1977)

\section{MANAGERIAL IMPLiCATiON}

Given the results of this study prove that the influence of Competence on Social Corporations, Job Satisfaction and Organizational Commitment that shows good results, it is expected that the Company can look for the right steps in order to increase the positive factors that support the creation of Job Satisfaction and Organizational Commitment things that are considered such as Competence and social exchange so that all involved in the company will run well and be in harmony with the company. As is known that if employees are satisfied with what the company does, they will always be competent and committed to the best for the company. This will also benefit the company so that it can progress and develop more. Employee satisfaction can then lead to loyalty to the company and make the company the last port in spending the rest of his career in the company, where if the commitment changes with loyalty to the company, the company can obtain benefits such as lowering the cost of searching new employees because employees have good and loyal organizational commitment to the company, more costs to do retraining because these competent employees can also reduce costs for finding new employees. Improving Company Performance that will enlarge the market share Employees will also be happy in doing the tasks that are given without any Thought thinking things that are done later will be mutually beneficial between the Company and employees. Other things to think about steps and strategies for maintain positive perceptions of Competence, Social Management, Job Satisfaction and Organizational Commitment

\section{REFERENCES}

1. Alldredge, M.E. \& K.J. Nilan (2000). 3M's leadership competency model: An internally developed solution. Human Resource Management, 39(2\&3), 133-145.

2. Alvi, H. A. (2014). Impact of Organizational Culture on Organizational Commitment and Job Satisfaction. European Journal of Business and Management, 30-39.

3. Al-sada, M. (2017). Influence of organizational culture and leadership style on employee satisfaction, commitment and motivation in the educational sector in Qatar. EuroMed Journal of Business, 163-188. 
Competency Analysis of Job Satisfaction and Organizational Commitment to Lecturers Who Teach at Private Universities in the Area of Southern Sumatra

4. Arrow, K. J. (1974). The Limits of Organization. Norton, New York.

5. Baron, A. R. \& Greenberg, J. (2003). Organizational Behaviour in Organization. Understanding and managing the human side of work. Canada: Prentice Hall

6. Blau, P. M. (1964). Exchange and power in social life. New York: John Wiley

7. Bowersox, d. J., daugherty, p. J., Droge, c. L., germain, r. N. And Rogers, d. S., (1992), Logistical Excellence: It's Not Business as Usual (Burlington: Digital).

8. Chen, H.C. \& S. Naquin (2006). An Integrative Model of Competency Development, Training

9. Cira, D.J. \& E.R. Benjamin, (1998). Competency-based pay: A concept in evolution. Compensation and Benefits Review, 30(5), 21-29

10. Cropanzano, R., Bowen, D.E., \& Gilliland, S.W. (2007). The Management Of Organizational Justice. Academy Of Management Perspectives, Vol. 21, No. 4, pp. 34 - 38.

11. Cropanzano, R. Byrne, Z.S., Bobocel, D.R., \& Rupp, D.E. (2001). Moral Virtues, Fairness Heuristics,

12. Cropanzano, R., Prehar, C.A., \& Chen, P.Y. (2000). Using social exchange theory to distinguish procedural from interactional justice. Group \& Organization Management Edy Sutrisno, (2014). Manajemen Sumber Daya Manusia. Cetak Ke Enam.Pranada Media Group, Jakarta.

13. Ellram, Lisa M. and Martha C. Cooper (1990), "Supply Chain Management, Partnerships, and the ShipperThird-Party Relationship," The International Journal of Logistics Management, Vol. 1, No. 2, pp. 1-10.

14. F. Oben Ürü Sanı (2016) how employees' perceptions of competency models affect job satisfaction? Mediating effect of social exchange. Academy of Strategic Management Journal Volume 15, Number

15. Graen, (1995). Cross-cultural leadership-making: Bridging American and Japanese diversity for team advantage. In: H.C. Triandis, M.D. Dunnette, \& L.M. Hough (Eds.), Handbook of Industrial and Organizational Psychology (Vol. 4, pp. 415- 446). New York: Consulting Psychologist Press

16. Green, P.C. (1999). Building robust competencies: Linking human resource systems to organizational strategies. San Francisco: Jossey-Bass

17. Gerstner, C. R., \& Day, D. V. 1997. "Meta-Analytic review of leader-member exchange theory: Correlates and construct issues". Journal of applied psychology, 82 (6), 827-844.

18. Hakansson, H., Snehota, I. (1995), Developing relationships in business network, Routledge, London Hill, J. (2012). Competency Model Helps HR Add Value. Canadian HR Reporter, 25(2), 20 - 22.

19. Hirschfeld, R.R. (2000). Validity studies. Does revising the intrinsic and extrinsic subscales of the Minnesota Satisfaction Questionnaire Short Form make a difference? Educational Psychological Measurement, 60, 255-270.

20. Juliwati, (2014). "Pengaruh Budaya Organisasi dan Motivasi Kerja Terhadap Kepuasan Kerja dan Kinerja Karyawan serta Dampaknya Terhadap Turnover Intention., Universitas Bina Nusantara.

21. Kei m. Nomaguchi and melissa a. Milkie (2004) costs and rewards of children:The effects of becoming a parent on adults' lives

22. Lalonde, P. (1992). Lower incidence and increased male: female ratio in schizophrenia. The British Journal of Psychiatry, 161(4), 556-557.

American Research Journal of Business and Management

Page 5 
Competency Analysis of Job Satisfaction and Organizational Commitment to Lecturers Who Teach at Private Universities in the Area of Southern Sumatra

23. Levine, H.Z. (1997). Human Resources. Compensation \& Benefits Review, 29(4), 61-64.

24. Masterson, S.S., K. Lewis, B.M. Goldman \& M.S. Taylor (2000). Integrating Justice and Social Exchange: The Differing Effects of Fair Procedures and Treatment on Work Relationships. Academy of Management Journal, 43(4), 738-748.

25. Meyer, J. P. (1997). Organizational commitment. In C. L. Cooper \& I. T. Robertson (Eds.), International review of Jornal

26. Morgan, R.M. and Hunt, S.D. (1994), "The commitment-trust theory of relationship marketing", Journal of Marketing, Vol. 58 No. 3, pp. 20-38.

27. Morgan, Robert M., dan Shelby D. Hunt, (1994), "The Commitment-Trust Theory of Relationship Marketing”, Journal of Marketing, Vol. 58, July, pp. 20- 38 industrial and organizational psychology: 175-228. New York: John Wiley

28. Mowday, R.T., Steers, R.M. and Porter, L.W. (1979), "The measurement of organizational commitment”, Journal of Vocational Behavior, Vol. 14, pp. 224-47.

29. Mirabile, R.J. (1997). Everything you always wanted to know about competency modeling. Training \& Development, 51(8), 73-77.

30. Nisfiannoor, Muhammad. (2013). Pendekatan Statistika Modern Untuk Ilmu Sosial edisi ke 2 (edisi Revisi). Jakarta : Salemba Humanika.

31. Redmond, E. (2011). An empirical exploration of the relationship between employee perceptions of competency model relevance and fairness and employee outcomes, Master's Dissertation, Norway: BI Norwegian Business School.

32. Redmond, E. (2013). Competency Models at Work: The Value of Perceived Relevance and Fair Rewards for Employee Outcomes. Human Resource Management, 52(5), 771-792.

33. Riaz, M. (2016). Impact of Job Stress on Employee Job Satisfaction. International Review of Management and Business Research , 1370-1382.

34. Robin and Judge, S. (2015). Organizational Behavior (Vol. 16). New Jersey: Pearson Education Inc

35. Sekaran, U. (2011). Research Methods for Business. USA: John Wiley \& Sons, Inc.

36. Shore, L. M., Tetrick, L. E., Lynch, P., \& Barksdale, K. (2006). Social and economic exchange: Construct developmentand validation. Journal of Applied Social Psychology, 36: 837-867.

37. Shore, L.M., J.A.M. Coyle-Shapiro \& L.E. Tetrick (2009). Social Exchange in Work Settings: Content, Process, and Mixed Models. Management and Organization Review, 5(3), 289-302.

38. Sugiyono. (2013). Metode Penelitian Pendidikan (Pendekatan Kuantitatif, Kualitatif dan R \& D). Bandung: Alfabeta.

39. Williamson, G. dan W.J.A. Payne, 1978. An Introduction to Animal Husbandry in The Tropics, Second Edition, ELBS and Longman Group Limited, London.

Citation: Zainal Berlian. "Competency Analysis of Job Satisfaction and Organizational Commitment to Lecturers Who Teach at Private Universities in the Area of Southern Sumatra" American Research Journal of Business and Management. 2018; 4(1): 1-6.

Copyright (c) 2018 Zainal Berlian. This is an open access article distributed under the Creative Commons Attribution License, which permits unrestricted use, distribution, and reproduction in any medium, provided the original work is properly cited. 